\title{
PENENTUAN DOSIS KAPORIT SEBAGAI DESINFEKTAN DALAM MENYISIHKAN KONSENTRASI AMMONIUM PADA AIR KOLAM RENANG
}

\author{
Dheasy Herawati ${ }^{1}$, Anton Yuntarso ${ }^{2}$ \\ ${ }^{1), 2)}$ Dosen Fakultas Ilmu Kesehatan, UMAHA, Sidoarjo \\ Email : dheasy15@gmail.com
}

\begin{abstract}
Disinfectant commonly used in water swimming pools is calcium hypochlorite $\left\{\mathrm{Ca}(\mathrm{OCl})_{2}\right\}$. Calcium hypochlorite is disinfectant which is used in the cleaning of water due to a searchable, inexpensive and contain approximately $70 \%$ chlorine. The use of calcium hypochlorite with improper doses will cause the formation of trihalomethane (THMs) compounds which are toxic and carcinogenic nature so that the use of calcium hypochlorite should be based on the calculation of Break Point Clorination (BPC) in order to secure for the environment. The purpose of the research was determine the opyimum dose of calcium hypochlorite in the form of crystal and solution for removal concentration of ammonium. The results obtained from the research that the optimum dose in the water swimming pools for disinfection process is not more than $10 \mathrm{~g} / \mathrm{L}$. The addition of calcium hypochlorite in the form of crystals can be removal the concentration of ammonium of $87.50 \%$ and in the form of aqueous solution of $83.30 \%$. so it can be deduced that the addition of calcium hypochlorite in the form of crystals better than as a solution to removal the concentration of ammonium.
\end{abstract}

Keywords: Disinfectant, calcium hypochlorite, BPC, Removal of Ammonium

\section{PENDAHULUAN}

Salah satu aspek yang harus diawasi dari sanitasi kolam renang adalah kualitas airnya yang harus memenuhi syarat, baik secara fisik, kimia, maupun mikrobiologi. Menurut Effendi (2004), kualitas air yang tersedia saat ini masih kurang memenuhi syarat kualitas air bersih, salah satunya berdasarkan syarat mikrobiologis air kolam renang masih mengandung bakteri patogen.

Pengawasan kualitas air kolam renang secara kimiawi termasuk salah satu upaya sanitasi yang dilakukan. Salah satunya adalah pemberian senyawa kimia berupa senyawa klor berupa kaporit $(\mathrm{Ca}(\mathrm{OCl} 2))$ yang berfungsi untuk mereduksi zat organik, mengoksidasi logam, dan sebagai desinfeksi terhadap mikroorganisme. Namun, penggunaan kaporit juga harus diperhatikan dengan baik dan harus sesuai dengan batas aman yang ada. Penggunaan kaporit dalam konsentrasi yang kurang dapat menyebabkan mikroorganisme yang ada di kolam renang tidak terdesinfeksi dengan baik. Sedangkan penggunaan kaporit dengan konsentrasi yang berlebih dapat meninggalkan sisa klor yang menimbulkan dampak buruk bagi kesehatan (Cita, dan Adriyani, 2013).

Kaporit dipilih sebagai desinfektan dalam pengolahan limbah cair karena menurut Said (2007), klor pada kaporit terutama HOCl umumnya sangat efektif untuk inaktivasi patogen dan bakteri indikator. Selain itu, menurut Ali (2010), kaporit digunakan sebagai desinfektan karena harganya yang lebih murah, lebih stabil dan lebih melarut dalam air. Klorin 
yang ditambahkan pada air kolam renang akan bereaksi membentuk hidroklorit, hidrogen dan klorida bebas (Sawyer, C.N., et al., 2003)

Klorin yang ditambahkan pada air kolam renang akan bereaksi dengan amoniak membentuk kloramin (monokloramin dan dikhloramin) pada awal penyisihan ammonium $\left(\mathrm{NH}_{4}{ }^{+}\right)$sampai ammonium $\left(\mathrm{NH}_{4}{ }^{+}\right)$hampir tersisih sempurna dan menghasilkan gas $\mathrm{N}_{2}$. Break Point Clorination (BPC) adalah Penentuan jumlah optimum klor untuk bereaksi dengan logam - logam, zat organik dan ammonia yang dibutuhkan untuk desinfeksi air dalam suatu wadah melalui proses pereaksian (Metcalf \& Eddy, Inc, 1991)

Penambahan kaporit harus sesuai dengan hasil yang didapat dari Break Point Chlorination (BPC) karena bila kurang dari hasil yang didapatkan akan mengakibatkan mikroorganisme yang ada di dalam air kolam renang tidak dapat tereduksi sempurna dan bila kelebihan penambahan kaporit bisa menyebabkan rasa gatal pada kulit akibat reaksi dari kalsium hipoklorit yang berlebih (Tchobanoglous, G, 1991) dan menyebabkan bau yang sangat menyengat dari phenol (Clesceri,L.S., et.al., 1998).

Bertolak dari masalah tersebut di atas perlu dilakukan penelitian untuk mendapatkan dosis optimum kaporit dalam bentuk kristal dan larutan, yang nilainya didapat dari hasil Break Point Chlorination (BPC) dalam menyisihkan konsentrasi ammonium $\left(\mathrm{NH}_{4}{ }^{+}\right)$.

\section{TINJAUAN PUSTAKA \\ Desinfektan}

Pada tahun 1850, desinfektan sudah dipakai dengan menggunakan metode klorinasi. Selama itu hipoklorit digunakan sebagai desinfektan sebelum adanya penelitian. Pada tahun 1912, penggunaan klorin sebagai desinfektan, penambahannya dilakukan secara sembarangan atau tidak sesuai dengan dosis yang tepat sehingga malah mengakibatkan penyakit. Penyakit yang terjadi seperti typhus, infeksi hepatitis dan juga bisa karena protozoa.
Dari sini maka Persatuan Negara melakukan penelitian dan menghasilkan kesimpulan bahwa penambahan desinfektan harus melalui perhitungan (Sawyer, C.N., et al, 2003).

Desinfektan merupakan bahan selektif yang digunakan untuk merusak penyakit yang disebabkan oleh organisme yang berasal dari bakteri, virus, dan amoeba. Pada proses ini organisme belum mati seluruhnya, berbeda dengan strerilisasi yang mana dapat membunuh seluruh organisme yang ada. Penyakit yang timbul misalnya thypus, kolera, parathypus, disentri, polimielitis dan infeksi hepatitis, sehingga diperlukan desinfektan dalam pembersihan air kolam renang.

Desinfektan umumnya diperoleh dari bahan kimia, bahan fisika, mekanik dan radiasi. Bahan kimia yang biasa digunakan adalah klorin dimana unsur ion-ionnya terdapat dalam senyawa kaporit. Desinfektan dari bahan fisika dapat berasal dari cahaya matahari. Radiasi ultraviolet sangat berguna dalam sterilisasi kualitas kecil pada air karena dapat membunuh molekul dari organik dan juga organisme. Desinfeksi secara mekanik mengutamakan kebersihan dari air kolam renang. Sedangkan desinfeksi secara radiasi menggunakan sinar gamma pada cara sterilisasi (Tchobanoglous, G, 1991).

\section{Kaporit}

Kaporit merupakan desinfektan yang umum digunakan dalam segala bentuk baik bentuk kering / kristal dan bentuk basah / larutan . Dalam bentuk kering, biasanya kaporit berupa serbuk atau butiran, tablet atau pil. Dalam bentuk basah biasanya kristal yang ada dilarutkan dengan aquadest menurut kebutuhan desinfeksi. Berdasarkan uji kaporit dalam laboratorium disebutkan bahwa kaporit terdiri lebih dari $70 \%$ bentuk klorin. Kaporit dalam bentuk butiran atau pil dapat cepat larut dalam air dan penyimpanannya ditempat kering yang jauh dari bahan kimia yang mengakibatkan 
korosi, dalam kondisi atau temperatur rendah, relatif stabil. Kaporit merupakan bahan yang mudah dicari, mudah penggunaannya, terjangkau oleh masyarakat umum (Tchobanoglous, G, 1991).

Kaporit / Kalsium hipoklorit pada proses desinfeksi bisa dengan cepat membunuh organisme yang ada di air kolam renang, dan juga bisa menyisihkan $\mathrm{NH}_{4}{ }^{+}$pada air kolam renang sehingga kadar dari ammoniak bisa berkurang dan tidak melampaui batas dari Standar Nasional Indonasia dimana air kolam renang merupakan air yang masuk dalam golongan 3 dimana kadar ammoniak bebas tidak boleh lebih dari $5 \mathrm{mg} / \mathrm{L}$.

Kelemahan klorinasi adalah adanya korelasi positif antara kaporit dengan senyawa organohalogen yang merupakan hasil reaksi antara klor dengan senyawa organik berhalogen $(\mathrm{CHCl})$ yang terdapat dalam limbah. Salah satu senyawa organohalogen adalah trihalometan (THM). Semakin tinggi konsentrasi kaporit, semakin tinggi pula probilitas terbentuknya THM. Trihalomentan bersifat karsinogenik dan mutagenik (Sururi, dkk. 2008). Untuk mengeliminasi terbentuknya THM, penentuan titik breakpoint clorination (BPC) menjadi penting sebelum aplikasi kaporit di lapangan. BPC adalah jumlah klor aktif (ion $\mathrm{OCl}^{-}$dan $\mathrm{HOCl}$ ) yang dibutuhkan untuk mengoksidasi semua bahan organik dan bahan anorganik yang terlarut dalam limbah dan kemudian sisa klor aktifnya berfungsi sebagai disinfektan (Lestari, dkk., 2008; Sururi, 2008; Brooks, 1999; Alaert dan Sumestri, 1984)

\section{Break Point Clorination (BPC)}

Break Point Clorination (BPC) adalah penentuan jumlah klor yang dibutuhkan dalam pereaksian, sehingga semua zat yang dapat dioksidasi menjadi teroksidasi, amoniak hilang sebagai gas $\mathrm{N}_{2}$, dan masih ada residu klor aktif terlarut yang konsentrasinya dianggap perlu untuk desinfeksi mikroorganisme (Santika, S.S., 1987).

Proses yang terjadi dari penambahan kaporit sampai didapatkan BPC adalah sebagai berikut : logam - logam zat organik seperti $\mathrm{Fe}^{2^{+}}, \mathrm{Mn}^{2+}, \mathrm{H}_{2} \mathrm{~S}$ dan organik lainnya akan bereaksi dengan klorin dan sebagian akan berubah menjadi ion klorida. Kelebihan klorin akan bereaksi dengan amoniak sehingga menghasilkan kloramin, jika jumlah $\mathrm{NH}_{3}$ ( amoniak ) lebih banyak dari klorin maka monokloramin dan dikloramin juga banyak terbentuk (pada awal penyisihan $\mathrm{NH}_{4}{ }^{+}$). Tetapi hal ini tergantung dari $\mathrm{pH}$ dan temperatur. Penambahan klorin secara terus menerus pada akhir breakpoint akan meningkatkan klorin bebas (yang tidak bereaksi dengan hipoklorit) sehingga peningkatan akan berlangsung selama breakpoint clorination beroperasi. Persen dari penambahan klorin akan bereaksi dengan nitrogen organik dan kemungkinan akan membentuk kurva breakpoint (Tchobanoglous, G., 1991).

Jumlah klorin yang harus ditambahkan untuk mencapai tingkat residu yang diinginkan disebut kebutuhan klorin. Dari grafik BPC yang telah diketahui kebutuhan klorinnya bisa digunakan untuk mendapatkan prosentase penyisihan dari ammonium $\left(\mathrm{NH}_{4}\right)$. Konsentrasi kaporit yang didapat dari hasil Break Point Chlorination (BPC) harus dikalikan dengan jumlah air yang akan didesinfektan untuk 
mendapatkan prosentase penyisihan ammonium $\left(\mathrm{NH}_{4}{ }^{+}\right)$yang optimum

(Clesceri, L.S., et al., 1998).

\section{METODOLOGI PENELITIAN}

\section{Tempat Penelitian}

Penelitian ini dilaksanakan di laboratorium kimia Fakultas Ilmu Kesehatan UMAHA Sidoarjo.

\section{Bahan Penelitian}

Bahan penelitian adalah air dari kolam renang di Pemandian Ubalan Pacet Mojokerto pada pagi hari sebelum penambahan desinfektan. Sampel air kolam renang diambil sebanyak 2 x 10 liter dalam kurun waktu selisih 1 minggu yaitu pada penelitian ke -1 dan penelitian ke -2 . Hal ini dikarenakan untuk perbandingan pada penambahan dosis kaporit. Contoh sampel diambil dari bagian kolam yang dalam, pada tempat air masuk dan tempat air keluar seperti pada gambar 1.

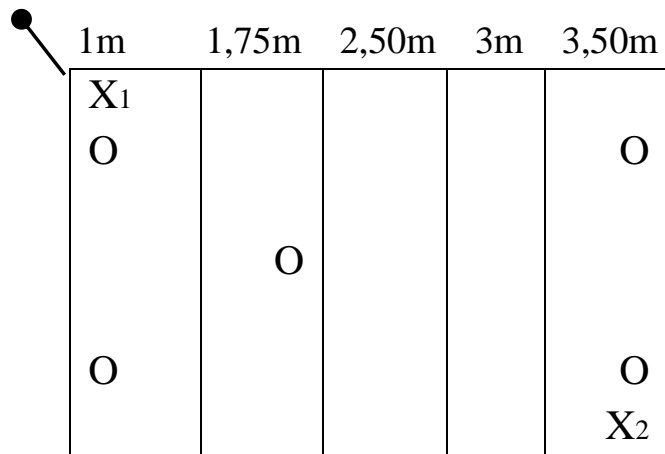

Gambar 1. Letak Pengambilan Sampel Keterangan:

$\mathrm{X}_{1}$ :Tempat air masuk, sampel diambil 1,5L $\mathrm{X}_{2}$ :Tempat air keluar, sampel diambil 1,5L $\mathrm{O}$ :Tepat di dasar kolam renang, sampel diambil

$1,5 \mathrm{~L}$.

\section{Cara Kerja}

\section{Pemeriksaan Kadar Ammonium}

Sebanyak 22 sampel air kolam renang diperiksa kadar ammoniumnya menggunakan metode Nessler secara kolorimetri sebelum dilakukan penambahan kaporit dengan konsentrasi yang berbeda.
Pada $25 \mathrm{ml}$ sampel ditambahkan 1,5 ml larutan Garam Signet dan 0,5 ml Nessler kemudian dikocok. Jika larutan sampel berwarna kuning coklat muda berarti Ammonium positif. Bandingkan dengan Blanko yang dititrasi dengan larutan Standar Ammonium klorida $\left(\mathrm{NH}_{4} \mathrm{Cl}\right) 0,1 \mathrm{mg} / \mathrm{L} \mathrm{NH}_{4}{ }^{+}$.

Konsentrasi

$$
\underset{(\mathrm{mg} / \mathrm{L})}{\mathrm{NH}_{4}^{+}}=\frac{1000}{25} \times \begin{array}{ccccc} 
& \begin{array}{c}
\text { Standar } \\
\mathrm{NH}_{4} \mathrm{Cl}
\end{array} & & \text { titran }
\end{array}
$$

\section{Analisa Residual Klorin Secara Iodometri}

Pada 22 erlenmeyer dimasukkan $25 \mathrm{ml}$ sampel air kolam renang dan ditambahkan sejumlah kaporit dengan konsentrasi 10 gram/L sesuai dengan tabel 2 dibawah ini, kemudian ditutup dan didiamkan selama 30 menit di tempat gelap.

Tabel 1. Tabel Penambahan Kaporit

\begin{tabular}{|c|c|c|c|}
\hline No & Kaporit (ml) & No & Kaporit $(\mathrm{ml})$ \\
\hline 1 & 0,5 & 12 & 2,8 \\
2 & 0,8 & 13 & 3,0 \\
3 & 1,0 & 14 & 3,2 \\
4 & 1,2 & 15 & 3,4 \\
5 & 1,4 & 16 & 3,6 \\
6 & 1,6 & 17 & 3,8 \\
7 & 1,8 & 18 & 4,0 \\
8 & 2,0 & 19 & 4,2 \\
9 & 2,2 & 20 & 4,4 \\
10 & 2,4 & 21 & 4,6 \\
11 & 2,6 & 22 & 4,8 \\
\hline
\end{tabular}

Berturut-turut ditambahkan $25 \mathrm{ml}$ larutan asam asetat glasial, 1 spatula kristal KI dan 3 tetes larutan amilum. Kemudian dititrasi dengan larutan natrium thiosulfat hingga warna kuning hilang dan dicatat kebutuhan volume titran.

Hasil titrasi dihitung residual klorinnya :

Residual Klorin $=\frac{1000}{25} \mathrm{X}$ ml titran $\mathrm{x} \mathrm{N}$ titran $\mathrm{x}$ 35,45

\section{Penentuan Dosis Optimum Kaporit dan Prosentase Penyisihan Ammonium}

Pembuatan grafik BPC dengan data konsentrasi kaporit akhir dan residual klorin. 
Dari grafik BPC dapat ditentukan dosis optimum kaporit dalam bentuk kristal dan larutan yang ditambahkan pada air kolam renang tiap liter nya.

Dosis optimum kaporit dikalikan dengan jumlah sampel untuk dimasukkan kedalam sampel air. Air kolam renang yang telah ditambah dosis optimum kaporit dalam bentuk kristal dan larutan dihitung kembali kadar ammoniumnya untuk mendapatkan prosentase penyisihan ammonium kemudian dihitung prosentase penyisihan (removal) ammonium dengan rumus sebagai berikut:

$$
\text { Removal NH} 4^{+}=\frac{\text { nilai } \mathrm{NH}^{4+(\text { sebelum-setelah })} \text { penambahan kaporit }}{\text { nilai } \mathrm{NH}^{4+} \text { sebelum penambahan kaporit }} \times 100 \%
$$

\section{Analisis Data}

Data dianalisa secara kuantitatif dan disajikan dalam bentuk grafik BPC dan tabulasi data untuk residual klorin serta prosentase penyisihan ammonium.

\section{HASIL DAN PEMBAHASAN}

Penentuan dosis optimum kaporit yang dibubuhkan dalam sampel air kolam renang berdasarkan kurva breakpoint chlorination. Secara teori titik BPC direpresentasikan oleh sebuah kurva yang mempunyai titik puncak maksimum dan titik puncak minimum. Titik puncak minimum inilah yang disebut titik BPC. Keuntungan dicapainya breakpoint yaitu senyawa ammonium teroksidisir sempurna (Joko, 2010), mematikan bakteri patogen secara sempurna dan mencegah pertumbuhan lumut. Waktu kontak diperkirakan merupakan faktor yang paling penting dalam proses desinfeksi. Semakin lama waktu kontak antara desinfektan

\section{Konsentrasi ammonium sebelum penambahan kaporit}

$\mathrm{mg} / \mathrm{L} \mathrm{NH}^{4+}=\frac{1000}{25} \times 0,1 \mathrm{mg} / \mathrm{L} x 1,8=7,2 \mathrm{mg} / \mathrm{L}$

Hasil dari BPC I = $3.4 \mathrm{ml}$ (penambahan kaporit)

Penambahan kaporit: $3,4 \times \frac{\mathrm{ml} \text { contoh yang akan didesinfektan }}{\mathrm{ml} \text { sampel untuk analisa }}$ $=3,4 \times \frac{5000}{25}=68 \mathrm{ml}$ dengan konsentrasi $10 \mathrm{~g} / \mathrm{L}$ dengan mikroba di dalam air, maka daya bunuhnya akan semakin besar (Budiyono dan Sumardiono, 2013).

Hasil residual klorin dengan penambahan kaporit dalam bentuk larutan dapat dilihat pada Tabel 2. dan grafik BPC I pada gambar 2, sedangkan data residual klorin dengan penambahan kaporit dalam bentuk kristal dapat dilihat pada tabel 3.dan grafik BPC II pada gambar 3.

Dari Tabel 2. dan Gambar 2. dapat diketahui bahwa residual klorin yang paling baik adalah pada konsentrasi kaporit 1197,18 mg/L. Jika penambahan kaporit dalam bentuk larutan dilakukan untuk proses desinfeksi adalah sebesar 3,4 $\mathrm{ml}$ dengan konsentrasi $10 \mathrm{~g} / \mathrm{L}$ dalam tiap $25 \mathrm{ml}$ sampel, maka untuk sampel air sebanyak 1 liter dibutuhkan $136 \mathrm{ml}$ kaporit dengan konsentrasi $10 \mathrm{~g} / \mathrm{L}$. Sehingga prosentase penyisihan ammonium yang didapat sebesar $83,30 \%$ dengan perhitungan sebagai berikut:

\section{Konsentrasi ammonium setelah penambahan kaporit}

$\mathrm{mg} / \mathrm{L} \mathrm{NH}^{4+}=\frac{1000}{25} \times 0,1 \mathrm{mg} / \mathrm{Lx} 0,3=1,2 \mathrm{mg} / \mathrm{L}$

\section{Removal / Penyisihan dari $\mathrm{NH}_{4}{ }^{+}$} $\% \mathrm{NH}_{4}^{+}$

$=\frac{\text { nilai } \mathrm{NH}^{4+}(\mathrm{seb}-\mathrm{set}) \text { penambahan kaporit }}{\text { nilai } \mathrm{NH}^{4+} \text { seb penambahan kaporit }} \times 100 \%$

$\% \mathrm{NH}^{+}=\frac{7,2-1,2}{7,2} \times 100 \%=83,30 \%$ 
Tabel 2. Tabel Hasil Penentuan Residual Klorin (penambahan kaporit dalam bentuk larutan)

\begin{tabular}{|c|c|c|c|c|c|c|c|}
\hline No & $\begin{array}{c}\text { Volume } \\
\text { Kaporit } \\
\text { Awal } \\
(\mathbf{m l})\end{array}$ & $\begin{array}{c}\text { Konsentrasi } \\
\text { Kaporit } \\
\text { Awal } \\
\text { (mg) }\end{array}$ & $\begin{array}{c}\text { Volume } \\
\text { Kaporit } \\
\text { Akhir } \\
(\mathbf{m l})\end{array}$ & $\begin{array}{c}\text { Konseentrasi } \\
\text { Kaporit } \\
\text { Akhir } \\
(\mathbf{m l})\end{array}$ & $\begin{array}{c}\text { Volume } \\
\text { Natrium } \\
\text { Thiosulfat } \\
(\mathbf{m l})\end{array}$ & $\begin{array}{c}\text { Konsentrasi } \\
\text { Natrium } \\
\text { Thiosulfat } \\
(\mathbf{N})\end{array}$ & $\begin{array}{c}\text { Residual } \\
\text { Klorin } \\
\text { (mg/L) }\end{array}$ \\
\hline 1 & 0,5 & 10.000 & 25,5 & 196.0784314 & 5,4 & 0,0125 & 95.715 \\
2 & 0,8 & 10.000 & 25,8 & 310.0775194 & 6,1 & 0,0125 & 108.1225 \\
3 & 1,0 & 10.000 & 26,0 & 384.6153846 & 8,2 & 0,0125 & 145.345 \\
4 & 1,2 & 10.000 & 26,2 & 458.0152672 & 9,7 & 0,0125 & 171.9325 \\
5 & 1,4 & 10.000 & 26,4 & 530.3030303 & 10,9 & 0,0125 & 193.2025 \\
6 & 1,6 & 10.000 & 26,6 & 601.5037594 & 11,5 & 0,0125 & 203.8375 \\
7 & 1,8 & 10.000 & 26,8 & 671.6417910 & 11,8 & 0,0125 & 209.155 \\
8 & 2,0 & 10.000 & 27,0 & 740.7407407 & 12,5 & 0,0125 & 221.5625 \\
9 & 2,2 & 10.000 & 27,2 & 808.8235294 & 12,6 & 0,0125 & 223.335 \\
10 & 2,4 & 10.000 & 27,4 & 875.9124088 & 12,8 & 0,0125 & 226.88 \\
11 & 2,6 & 10.000 & 27,6 & 942.0289855 & 13,0 & 0,0125 & 230.425 \\
12 & 2,8 & 10.000 & 27,8 & 1007.194245 & 14,0 & 0,0125 & 248.15 \\
13 & 3,0 & 10.000 & 28,0 & 1071.428571 & 14,5 & 0,0125 & 257.0125 \\
14 & 3,2 & 10.000 & 28,2 & 1134.751773 & 15,1 & 0,0125 & 267.6475 \\
15 & 3,4 & 10.000 & 28,4 & 1197.183099 & 10,2 & 0,0125 & $\mathbf{1 8 0 . 7 9 5}$ \\
16 & 3,6 & 10.000 & 28,6 & 1258.741259 & 20,0 & 0,0125 & 354.5 \\
17 & 3,8 & 10.000 & 28,8 & 1319.444444 & 22,0 & 0,0125 & 389.95 \\
18 & 4,0 & 10.000 & 29,0 & 1379.310345 & 22,7 & 0,0125 & 402.3575 \\
19 & 4,2 & 10.000 & 29,2 & 1438.356164 & 23,1 & 0,0125 & 409.4475 \\
20 & 4,4 & 10.000 & 29,4 & 1496.598639 & 23,6 & 0,0125 & 418.31 \\
21 & 4,6 & 10.000 & 29,6 & 1554.054054 & 24,0 & 0,0125 & 425.4 \\
22 & 4,8 & 10.000 & 29,8 & 1610.738255 & 24,4 & 0,0125 & 432.49 \\
\hline
\end{tabular}

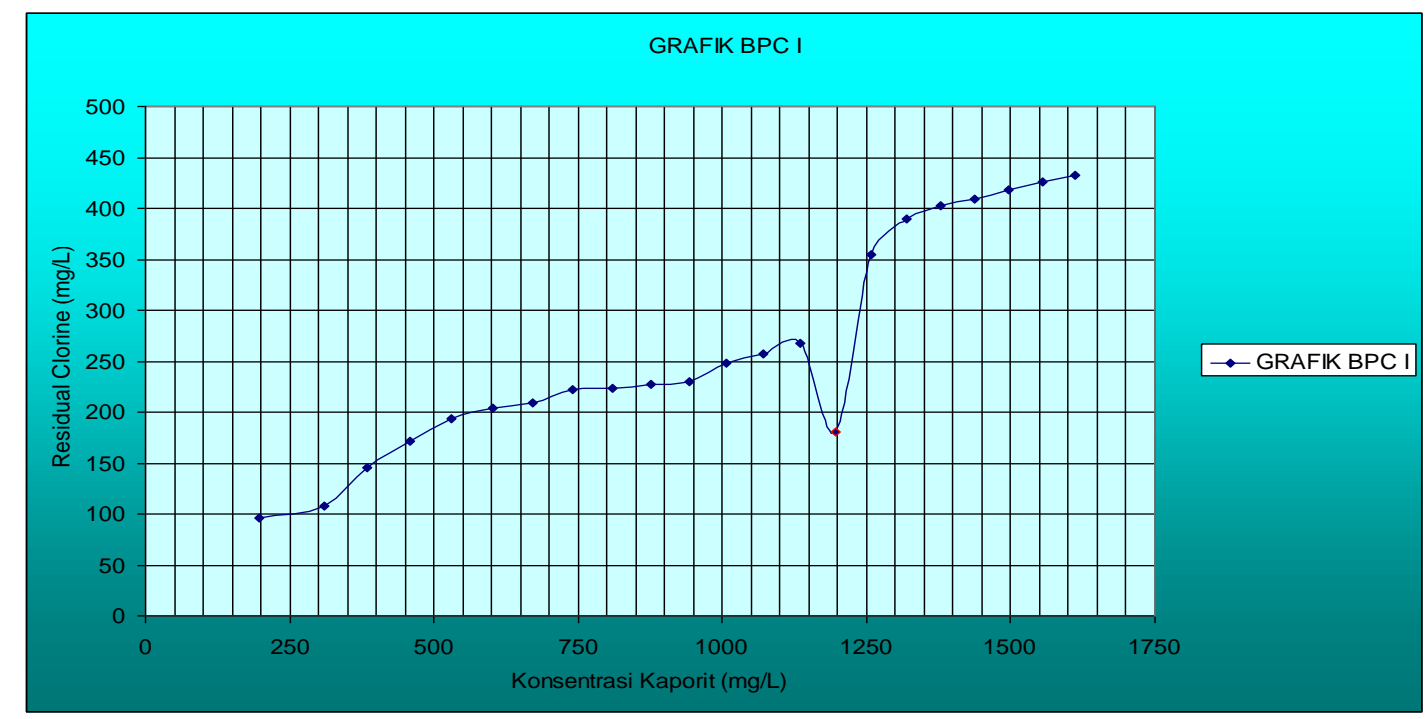

Gambar 2. Grafik BPC I (kaporit dalam bentuk larutan) 
Jurnal SainHealth Vol. 1 No. 2 Edisi September 2017

(C) Fakultas Ilmu Kesehatan Universitas Maarif Hasyim Latif Sidoarjo

p-ISSN : 2548-8333

e-ISSN : 2549-2586

Tabel 3. Tabel Hasil Penentuan Residual Klorin (penambahan kaporit dalam bentuk kristal)

\begin{tabular}{|c|c|c|c|c|c|c|c|}
\hline No & $\begin{array}{c}\text { Volume } \\
\text { Kaporit } \\
\text { Awal } \\
\text { (ml) }\end{array}$ & $\begin{array}{c}\text { Konsentrasi } \\
\text { Kaporit } \\
\text { Awal } \\
\text { (mg) }\end{array}$ & $\begin{array}{c}\text { Volume } \\
\text { Kaporit } \\
\text { Akhir } \\
\mathbf{( m l )}\end{array}$ & $\begin{array}{c}\text { Konseentrasi } \\
\text { Kaporit } \\
\text { Akhir } \\
(\mathbf{m l})\end{array}$ & $\begin{array}{c}\text { Volume } \\
\text { Natrium } \\
\text { Thiosulfat } \\
(\mathbf{m l})\end{array}$ & $\begin{array}{c}\text { Konsentrasi } \\
\text { Natrium } \\
\text { Thiosulfat } \\
\text { (N) }\end{array}$ & $\begin{array}{c}\text { Residual } \\
\text { Klorin } \\
(\mathbf{m g} / \mathbf{L})\end{array}$ \\
\hline 1 & 0,5 & 10.000 & 25,5 & 196.0784314 & 7,4 & 0,0125 & 130.68288 \\
2 & 0,8 & 10.000 & 25,8 & 310.0775194 & 7,6 & 0,0125 & 134.31296 \\
3 & 1,0 & 10.000 & 26,0 & 384.6153846 & 8,0 & 0,0125 & 141.57312 \\
4 & 1,2 & 10.000 & 26,2 & 458.0152672 & 8,4 & 0,0125 & 148.83328 \\
5 & 1,4 & 10.000 & 26,4 & 530.3030303 & 8,5 & 0,0125 & 150.64832 \\
6 & 1,6 & 10.000 & 26,6 & 601.5037594 & 8,6 & 0,0125 & 152.46336 \\
7 & 1,8 & 10.000 & 26,8 & 671.6417910 & 8,9 & 0,0125 & 157.90848 \\
8 & 2,0 & 10.000 & 27,0 & 740.7407407 & 9,3 & 0,0125 & 165.16864 \\
9 & 2,2 & 10.000 & 27,2 & 808.8235294 & 22,7 & 0,0125 & 402.93888 \\
10 & 2,4 & 10.000 & 27,4 & 875.9124088 & 10,8 & 0,0125 & 190.5792 \\
11 & 2,6 & 10.000 & 27,6 & 942.0289855 & 10,6 & 0,0125 & 188.76416 \\
12 & 2,8 & 10.000 & 27,8 & 1007.194245 & 9,7 & 0,0125 & 172.4288 \\
13 & 3,0 & 10.000 & 28,0 & 1071.428571 & 9,4 & 0,0125 & 166.98368 \\
14 & 3,2 & 10.000 & 28,2 & 1134.751773 & 9,2 & 0,0125 & $\mathbf{1 6 3 . 3 5 3 6}$ \\
15 & 3,4 & 10.000 & 28,4 & 1197.183099 & 11,3 & 0,0125 & 199.6544 \\
16 & 3,6 & 10.000 & 28,6 & 1258.741259 & 11,8 & 0,0125 & 208.7296 \\
17 & 3,8 & 10.000 & 28,8 & 1319.444444 & 12,3 & 0,0125 & 217.8048 \\
18 & 4,0 & 10.000 & 29,0 & 1379.310345 & 12,9 & 0,0125 & 228.69504 \\
19 & 4,2 & 10.000 & 29,2 & 1438.356164 & 13,5 & 0,0125 & 239.58528 \\
20 & 4,4 & 10.000 & 29,4 & 1496.598639 & 14,3 & 0,0125 & 254.1056 \\
21 & 4,6 & 10.000 & 29,6 & 1554.054054 & 15,3 & 0,0125 & 270.44096 \\
& & & & & & & \\
\hline
\end{tabular}

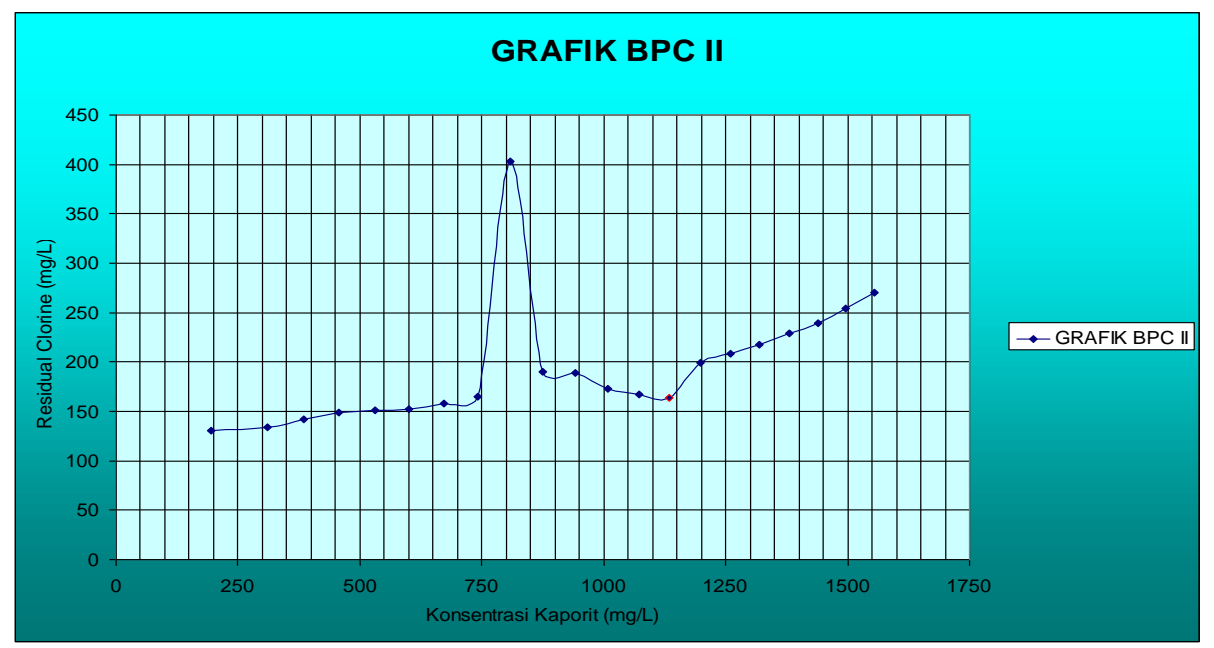

Gambar 3. Grafik BPC II (kaporit dalam bentuk kristal)

Dari Grafik BPC II diketahui bahwa residual klorin yang paling baik adalah pada konsentrasi kaporit 1134,75 mg/L, sehingga penambahan kaporit dalam bentuk kristal sebanyak $1134 \mathrm{mg}$ untuk 1 liter sampel air. Sehingga prosentase penyisihan ammonium yang didapat sebesar $87,50 \%$ dengan perhitungan sebagai berikut:

\section{Konsentrasi ammonium sebelum penambahan kaporit}

$$
\begin{aligned}
\mathrm{NH}^{4+}(\mathrm{mg} / \mathrm{L}) & =\frac{1000}{25} \times \operatorname{std~} \mathrm{NH}^{4} \mathrm{Cl} \times \mathrm{ml} \text { titran } \\
\mathrm{mg} / \mathrm{L} \mathrm{NH}_{4}{ }^{+} & =\frac{1000}{25} \times 0.1 \mathrm{mg} / 1 \times 1.6 \\
& =6,4 \mathrm{mg} / \mathrm{L}
\end{aligned}
$$


Hasil dari BPC II = $1.134 \mathrm{mg} / \mathrm{L}$ (penambahan kaporit )

Penambahan kaporit $=1.134 \mathrm{x}$ jumlah sampel

$$
=1.134 \times 9 \text { liter }
$$$$
=10.206 \mathrm{mg} / \mathrm{L}
$$

\section{Konsentrasi ammonium setelah penambahan kaporit}

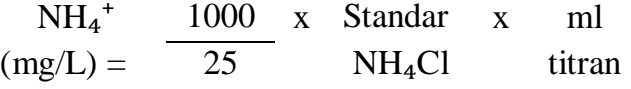

$$
\begin{aligned}
& \mathrm{NH}_{4}{ }^{+}=\frac{1000}{25} \times \quad 0.1 \mathrm{mg} / 1 \quad \text { x } \quad 0.2 \\
& =0,8 \mathrm{mg} / \mathrm{L}
\end{aligned}
$$

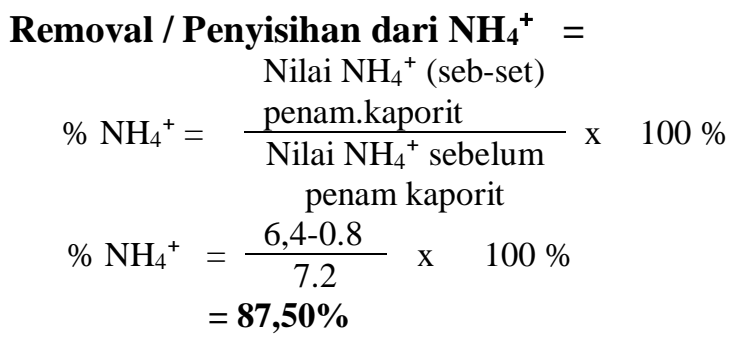

Dalam menentukan dosis kaporit digunakan metode iodometri dimana sampel dengan penambahan kaporit dalam jumlah tertentu akan ditritasi menggunakan larutan standar Natrium Thiosulfat (Sawyer, C.N, et all, 2003). Kemudian hasil yang didapat, dihitung kadar residual klorin selanjutnya dibuat kurva untuk mengetahui letak Break Point Chlorination (BPC). Dari kurva Break Point Chlorination (BPC) dapat diketahui dosis optimum kaporit dalam bentuk larutan dan kristal, kemudian digunakan untuk mengetahui prosentase removal $\mathrm{NH}_{4}{ }^{+}$setelah penambahan kaporit.

Menurut Rosyidi (2010), residu klor aktif yang terdeteksi melalui titrasi iodometri adalah klor bebas ( $\mathrm{HOCl}$ dan ion $\mathrm{OCl}-$ ) dan klor terikat. Perbandingan $\mathrm{HOCl}$ dan $\mathrm{OCl}-$ tergantung pada $\mathrm{pH}$ air. Klor sebagai $\mathrm{HOCl}$ dan OCl- disebut sebagai klorin bebas yang tersedia (free available chlorine) (Said, 2007).

Pemeriksaan kadar ammonium menggunakan metode Nessler secara kolorimetri.
Reaksi Ammonium dengan reagen Nessler :

$$
\begin{aligned}
& 2 \mathrm{~K}_{2} \mathrm{HgI}_{4}+\mathrm{NH}_{4}+4 \mathrm{KOH} \leftrightarrow \\
& \mathrm{NH}_{2} \mathrm{Hg}_{2} \mathrm{OI} \downarrow+7 \mathrm{KI}+3 \mathrm{H}_{2} \mathrm{O}
\end{aligned}
$$

Endapan yang terjadi adalah merkurium (II) amidoiodida basa $\left(\mathrm{NH}_{2} \mathrm{Hg}_{2} \mathrm{OI}\right)$ yang berwarna kuning coklat.

Sampel dengan jumlah tertentu yang ditambahkan dengan larutan Garam Signet berfungsi mencegah gangguan ion $\mathrm{Ca}, \mathrm{Mg}, \mathrm{Fe}$ dan Sn yang dapat menimbulkan kekeruhan, kemudian ditambah reagen Nessler yang akan menghasilkan endapan merkurium (II) amidoidida basa yang berwarna kuning coklat yang menunjukkan bahwa didalam sampel terdapat ammonium (Setiono, L., dkk., 1995 )

Penambahan kaporit dalam bentuk kristal ke dalam air kolam renang sebanyak 1.134 $\mathrm{mg} / \mathrm{L}$ sehingga dapat meremoval $\mathrm{NH}_{4}{ }^{+}$sebesar $87.50 \%$ sedangkan dalam bentuk larutan sebesar 83,30\% dengan penambahan larutan kaporit sebanyak $680 \mathrm{ml}$ dengan konsentrasi 10 $\mathrm{g} / \mathrm{L}$.

Daya removal kaporit dalam bentuk kristal lebih besar dari bentuk larutan karena massa zat terlarut kristal lebih besar dari bentuk larutan. Penambahan kaporit pada bentuk kristal, langsung ditaburkan ke air kolam renang dengan berat tertentu sementara bentuk larutan ada proses pelarutan dulu dari bentuk kristal baru ditambahkan larutan tersebut ke dalam air kolam renang dengan volume yang terukur. Hal ini sesuai dengan pernyataan Mulyanto dan Isman (2008) jika kaporitnya murni, untuk memperoleh kadar yang tepat dalam air minum dibutuhkan 6-10 gram kaporit tiap 1.000 liter air. Namun jika kaporit yang dimiliki hanya berkonsentrasi $50 \%$, dosis kaporit yang digunakan menjadi dua kali lipat, yaitu 12-20 gram tiap 1.000 liter air. Sehingga kaporit bisa digunakan sebagai desinfektan yang baik karena memiliki daya removal yang cukup besar (Santika, S.S., 1987). 


\section{DAFTAR PUSTAKA}

Ali, M., 2010. Peran Proses Desinfeksi dalam Upaya Peningkatan Kualitas Produk Air Bersih. Universitas Pembangunan Veteran Nasional, Surabaya.

Cita, Dian Wahyu dan Adriyani, Retno., 2013. Kualitas Air dan Keluhan Kesehatan Pengguna Kolam Renang di Sidoarjo. Journal Kesling Vol.7 No.1 Juli 2013.

Clesceri, L.S., Greenberg, A.E., Eaton, A.D, 1998. Standard Methods for the Examination of Water and Wastewater. American Public Health Association. Washington DC.

Joko. T. 2010. Unit Produksi Sistem Penyediaan Air Minum. Graha Ilmu, Yogyakarta.

Lestari, D.E., Utomo, S.B., Sunarko, Virkyanov, 2008. Pengaruh Penambahan Biosida Pengoksidasi Terhadap Kandungan Klorin untuk Pengendalian Pertumbuhan Mikroorganisme pada Air Pendingin Sekunder RSG-GAS. Pusat Reaktor Serba Guna-BATAN. Kawasan Puspitek Serpong. Tangerang. Banten.

Said, N.I., 2007. Desinfeksi untuk Proses Pengolahan Air Minum. Jurnal Air Indonesia, 3(1):15-20.

Santika, S.S., Alaerts, G. 1984 . Metoda Penelitian Air. Usaha Nasional. Surabaya

Sawyer, C.N., McCarty, P.L., Parkin, G.F. 1994 . Chemistry for Enviromental Engineering and Science. McGrawHill. New York

Setiono, L., Pudjaatmaka, A.H. 1997. Buku Ajar Vogel KImia Analisis Kuantitatif Anorganik. EGC. Jakarta.

Sururi, R. M., Rachmawati, S.Dj., Sholichah, M.,. 2008. Perbandingan Efektifitas Klor dan Ozon sebagai Desinfektan pada Sampel Air dari Unit Filtrasi Instalasi PDAM Kota Bandung. Prosiding Seminar Nasional
Sains dan Teknologi-II 2008 Universitas Lampung.

Rosyidi, M.B., 2010. Pengaruh Breakpoint Chlorination (BPC) terhadap Jumlah Bakteri Koliform dari Limbah Cair Rumah Sakit Umum Sidoarjo. Institut Teknologi Surabaya, Surabaya.

Tchobanoglous, G., Burton, F.L. 1991. Wastewater Engineering Treatment Disposal Reuse. McGraw-Hill. New York 